\title{
Influence of the synthesis route on the electrochemical properties of $\mathrm{LiNi}_{0.425} \mathrm{Mn}_{0.425} \mathrm{CO}_{0.15} \mathrm{O}_{2}$
}

\author{
Nicolas Tran, Laurence Croguennec, C. Jordy, Ph. Biensan, Claude Delmas
}

\begin{abstract}
:
$\mathrm{LiNi}_{0.425} \mathrm{Mn}_{0.425} \mathrm{CO}_{0.15} \mathrm{O}_{2}$ " has been synthesized by three different methods at $1000{ }^{\circ} \mathrm{C}$ for $12 \mathrm{~h}$ in air: (1) coprecipitation of a mixed nickel, manganese and cobalt hydroxide and then removal of the solvents by evaporation, (2) same precipitation conditions as (1) but the solvents were removed by freeze-drying, (3) a mixed nickel, manganese and cobalt hydroxide was prepared from coprecipitation of the transition metal ions into lithium hydroxide only and, after washing and drying, the hydroxide was mixed with lithium carbonate and calcined at $1000^{\circ} \mathrm{C}$ for $12 \mathrm{~h}$ in air. Chemical titrations, X-ray diffraction analyses by the Rietveld method and magnetic measurements showed that very similar overall chemical formula and cationic distributions were obtained for "LiNi ${ }_{0.425} \mathrm{Mn}_{0.425} \mathrm{Co}_{0.15} \mathrm{O}_{2}$ " synthesized by the three different methods. However, scanning electron micrographs, particle size distribution and specific surface area measurements showed textural differences in the three "LiNi ${ }_{0.425} \mathrm{Mn}_{0.425} \mathrm{Co}_{0.15} \mathrm{O}_{2}$ " samples, which are believed to play a key role in the electrode preparation and thus to explain the differences observed in the electrochemical behavior in lithium battery
\end{abstract}

Keywords : Layered oxides; X-ray diffraction; Scanning electron microscopy; Specific surface area; Particle size distribution; Lithium-ion battery

\section{Introduction}

The layered material $\mathrm{LiCoO}_{2}$ is largely used as positive electrode material in the current commercial lithium-ion batteries, however, because of its high cost, the development of new positive electrode materials is required. $\mathrm{LiNiO}_{2}$ was suggested as an alternative material owing to its lower cost and higher specific capacity [1], [2], [3], [4] and [5]. Nevertheless, many drawbacks were found, such as the difficulty to prepare stoichiometric $\mathrm{LiNiO}_{2}$ materials [6], [7] and [8], a poor capacity retention upon long range cycling [9] and a low thermal stability in the charged state [10], [11] and [12]. Many research studies performed in the last fifteen years led to an improvement of all these properties, the effect of partial substitution for nickel ions was studied: Co [13], [14], [15], [16] and [17], Al [11], [18], [19], [20] and [21], Mg [22], Mn [23], [24], [25] and [26], Ti [23], [25] and [27], $\mathrm{Fe}[28], \mathrm{Ga}[29], \mathrm{Nb}[30], \ldots .$. Substituted $\mathrm{LiNiO}_{2}$ (mainly cobalt and aluminium substituted) with optimized properties is now available at large industrial scale, which allows its use in big "industrial" Li ion batteries [31].

Recently Ohzuku and Makimura, Koyama et al. and Ohzuku et al. have proposed the $\mathrm{LiNi}_{1 / 2} \mathrm{Mn}_{1 / 2} \mathrm{O}_{2}$ material, with high thermal stability and very good electrochemical performances [32], [33], [34] and [35]. In the $\mathrm{LiNi}_{1 / 2} \mathrm{Mn}_{1 / 2} \mathrm{O}_{2}$ phase nickel ions are divalent while manganese ions are tetravalent. Therefore only nickel ions are electrochemically active in this material and can be oxidized successively to the trivalent and tetravalent states. This point is very important for the stability of deintercalated materials. For the $\mathrm{Li}_{0.5} \mathrm{Ni}_{1 / 2} \mathrm{Mn}_{1 / 2} \mathrm{O}_{2}$ composition all nickel ions are in the trivalent state while in $\mathrm{Li}_{0.5} \mathrm{NiO}_{2}$ half of them are tetravalent, the other half being trivalent. As $\mathrm{Mn}^{4+}$ ions are thermally stable and $\mathrm{Ni}^{4+}$ ions very unstable a considerable improvement of the thermal stability of the deintercalated materials is observed for the $\mathrm{Li}_{x} \mathrm{Ni}_{1 / 2} \mathrm{Mn}_{1 / 2} \mathrm{O}_{2}$. Another interesting point about this peculiar composition concerns the absence of $\mathrm{Mn}^{3+}$ ions whatever the lithium intercalation state. It is well known that these cations have the strong tendency to migrate to the interslab space upon cycling leading to the formation of spinel-type phases [36], [37] and [38]. The capacity fading and polarization for $\mathrm{Li} / / \mathrm{LiNi}_{1 / 2} \mathrm{Mn}_{1 / 2} \mathrm{O}_{2}$ cells were shown to strongly depend on the synthesis route, which requires a high expertise [33], [39], [40] and [41].

As the cobalt substitution for nickel resulted in improving the electrochemical performances of lithium nickel oxide and in stabilizing its structure [14], [17] and [42], the partial substitution of cobalt for nickel and manganese has been investigated by several research groups [43], [44], [45], [46], [47], [48], [49], [50], [51], [52], [53], [54], [55] and [56]. In order to preserve the very interesting properties of $\mathrm{LiNi}_{1 / 2} \mathrm{Mn}_{1 / 2} \mathrm{O}_{2}$ it was of interest to study the $\mathrm{LiNi}_{1 / 2-y / 2} \mathrm{Mn}_{1 / 2-y / 2} \mathrm{Co}_{y} \mathrm{O}_{2}$ 
$(0<y<1)$ materials also characterized by a $\mathrm{Ni} / \mathrm{Mn}$ ratio equal to unity and thus belonging to the solid solution between $\mathrm{LiNi}_{1} / 2 \mathrm{Mn}_{1 / 2} \mathrm{O}_{2}$ and $\mathrm{LiCoO}_{2}$. Very good electrochemical performances were obtained for the material $\mathrm{LiNi}_{1 / 3} \mathrm{Mn}_{1 / 3} \mathrm{Co}_{1 / 3} \mathrm{O}_{2}$ by Ohzuku's group (160 mAh/g over 2.5-4.4 V) [24], [45], [56] and [57] with an improved thermal behavior versus that of charged lithium nickel oxide or lithium cobalt oxide [58]. Recently, refinements by the Rietveld method of the X-ray diffraction patterns recorded for the layered materials $\mathrm{LiNi}_{1-y-z} \mathrm{Mn}_{y} \mathrm{Co}_{z} \mathrm{O}_{2}$ showed that the transition metal disorder between the slab and the interslab space decreases with increasing cobalt concentration and increases with increasing nickel concentration [47]. The influence of manganese content on the morphology and electrochemical performances of the $\mathrm{LiNi}_{1-y-z} \mathrm{Mn}_{y} \mathrm{Co}_{z} \mathrm{O}_{2}$ materials was also pointed out and showed the importance of the particle size and morphology on cyclability of these materials [50].

This paper reports on the structure and the electrochemical behavior of " $\mathrm{LiNi}_{0.425} \mathrm{Mn}_{0.425} \mathrm{Co}_{0.15} \mathrm{O}_{2}$ ". This composition was chosen as a compromise between the increase of electrochemical performances due to cobalt and the increase of thermal stability due to the $\mathrm{Mn}^{4+}$ ions. The cost of the material was also taken into account in the choice of a relatively low amount of cobalt. "LiNi ${ }_{0.425} \mathrm{Mn}_{0.425} \mathrm{CO}_{0.15} \mathrm{O}_{2}$ " was prepared by various synthesis routes in order to optimize its electrochemical performances versus synthesis conditions and to find out if this material can be used as a possible alternative to $\mathrm{LiCoO}_{2}$ and $\mathrm{Li}(\mathrm{Ni}, \mathrm{Co}, \mathrm{Al}) \mathrm{O}_{2}$ in lithium-ion batteries.

\section{Experimental}

" $\mathrm{LiNi}_{0.425} \mathrm{Mn}_{0.425} \mathrm{CO}_{0.15} \mathrm{O}_{2}$ " was prepared using three different methods. The first one, named classical coprecipitation, consists in the coprecipitation of a mixed hydroxide in aqueous solution [59]. A mixed $(1 \mathrm{M})$ aqueous solution of $\mathrm{Ni}\left(\mathrm{NO}_{3}\right)_{2} \cdot 6 \mathrm{H}_{2} \mathrm{O}\left(97 \%\right.$ Prolabo), $\mathrm{Mn}\left(\mathrm{NO}_{3}\right)_{2} \cdot 4 \mathrm{H}_{2} \mathrm{O}(98 \% \mathrm{Fluka})$ and $\mathrm{Co}\left(\mathrm{NO}_{3}\right)_{2} \cdot 6 \mathrm{H}_{2} \mathrm{O}(98 \%$ Prolabo) prepared with the 42.5 / 42.5 / $15 \mathrm{Ni} / \mathrm{Mn} /$ Co molar ratio was added dropwise through a buret into a basic solution ( $\mathrm{LiOH} 1 \mathrm{M}$ (98+\% AlfaAesar) / $\mathrm{NH}_{4} \mathrm{OH} 3 \mathrm{M}$ (28$30 \%$ J.T. Baker)) under magnetic stirring. Note that the initial ratio $\mathrm{Li} /(\mathrm{Ni}+\mathrm{Co}+\mathrm{Mn}$ ) was adjusted to unity in order to prevent the formation of the $\mathrm{Li}_{1+x}\left(\mathrm{Ni}_{0.425} \mathrm{Mn}_{0.425} \mathrm{Co}_{0.15}\right)_{1-x} \mathrm{O}_{2}$ overlithiated phases [60]. A green-brown mixed hydroxide was precipitated. Water was removed by evaporation at 80 ${ }^{\circ} \mathrm{C}$ under primary vacuum using a rotavapor device. The resulting precipitate was dried overnight at $105^{\circ} \mathrm{C}$, precalcined at $500{ }^{\circ} \mathrm{C}$ for $5 \mathrm{~h}$ in air and then calcined at $1000{ }^{\circ} \mathrm{C}$ for $12 \mathrm{~h}$ in air in a tubular furnace. Heating up speed was fixed to $5^{\circ} \mathrm{C} / \mathrm{min}$ and cooling down speed was fixed to $4{ }^{\circ} \mathrm{C} / \mathrm{min}$. The second method, named freeze-drying coprecipitation, is similar to the first one concerning the precipitation conditions, except that the whole mixture after precipitation was freeze-dried to remove water in the solid state at $-20^{\circ} \mathrm{C}$ under primary vacuum, for $24 \mathrm{~h}$ in the case of a $200 \mathrm{~mL}$ solution. The third method, named hydroxide route, consists in precipitating a mixed hydroxide in lithium hydroxide. After washing to remove the lithium nitrates formed during precipitation and drying at $105^{\circ} \mathrm{C}$ overnight, the resulting powder was mixed with the appropriate amount of lithium carbonate and heated at $1000{ }^{\circ} \mathrm{C}$ for $12 \mathrm{~h}$ in air. During the heating and the cooling, the temperature variation was fixed to $2^{\circ} \mathrm{C} / \mathrm{min}$.

The average oxidation state of the transition metal ions was determined by iodometric titration with $\mathrm{Na}_{2} \mathrm{~S}_{2} \mathrm{O}_{3}$. The average mass percentage of metal ions was checked by complexometric titration with EDTA.

The samples were characterized by X-ray diffraction (XRD) using a Siemens D5000 diffractometer equipped with a graphite diffracted-beam monochromator and $\mathrm{Cu}$ Ka radiation. The diffraction patterns were recorded in the $5-80^{\circ}(2 \theta)$ range using $0.02^{\circ}(2 \theta)$ step of a $1 \mathrm{~s}$ duration for routine characterization. For structural study by the Rietveld method, data were collected in the $5-120^{\circ}$ $(2 \theta)$ range in steps of $0.02^{\circ}(2 \theta)$ with a constant counting time of $40 \mathrm{~s}$.

Magnetic measurements were carried out with a Superconducting Quantum Interface Device (quantum design MPMS-5S). Magnetization vs. field plots were recorded at $5 \mathrm{~K}$ over the $[-2000$ $\mathrm{Oe} ;+2000 \mathrm{Oe}$ ] range. The $H / M$ ratio $(H$ applied field of 10000 Oe and $M$ measured magnetization) was measured in the $[5-300 \mathrm{~K}]$ temperature range.

Scanning electron micrographs were collected with a Hitachi S4500 field emission microscope with an accelerating voltage of $5.0 \mathrm{kV}$. The samples were coated with a $2 \mathrm{~nm}$ platinum layer in order to prevent charge accumulation on their surface during the analysis.

Particle size measurements were performed using a Malvern Hydro $2000 \mathrm{G}$ apparatus. Various dispersant media were tested and the ultra-sonics time was optimized so that the particle size 
distribution was stable. The dispersant medium was distilled water and ultra-sonics were applied for five minutes before measurement.

Specific surface area measurements were carried out by the Brunauer, Emmet and Teller (B. E. T.) method with a Micromeritics Flowsorbs II 2300 device. Samples were dried overnight under nitrogen stream at $120^{\circ} \mathrm{C}$ before measurement.

Electrochemical properties of "LiNi $0.425 \mathrm{Mn}_{0.425} \mathrm{CO}_{0.15} \mathrm{O}_{2}$ " were studied in lithium cells containing a lithium foil as negative electrode. The positive electrodes consisted of a mixture of $88 \mathrm{wt} \%$ of active material, $10 \mathrm{wt} . \%$ of carbon black / graphite $(1: 1)$ and $2 \mathrm{wt} . \%$ of polytetrafluoroethylene as binder. Cells were assembled in an argon-filled dry box and cycled at room temperature in galvanostatic mode at a constant $C / 20$ rate (corresponding to a theoretical exchange of one electron per formula during charge or discharge).

\section{Results and discussion}

\subsection{Structural characterization}

The XRD patterns of " $\mathrm{LiNi}_{0.425} \mathrm{Mn}_{0.425} \mathrm{Co}_{0.15} \mathrm{O}_{2}$ " obtained by the three synthesis routes are reported in Fig. $1 \mathrm{a}-\mathrm{c}$. All the diffraction peaks can be indexed based on a hexagonal cell (a-NaFeO $\mathrm{N}_{2}$ pe structure; S.G.: R-3m). Phase purity was achieved and the narrowness of the diffraction lines $\left(\mathrm{FWHM}_{(104)}<0.16^{\circ}\right)$ indicates a good crystallinity for the three materials and suggests an homogeneous distribution of the cations within the structure. The splitting of the (018) / (110) doublet and the intensity ratio of the (003) / (104) diffraction lines superior to unity suggest a good 2D character for the structure [61] and [62].

The chemical titrations showed an average oxidation state (oxid. state) for the transition metal ions equal, as expected, to about 3 for the three materials. These values are reported in Table 1. Given the accuracy of the chemical titrations, the average oxidation state can be considered to be equal to 3 for the three materials and the Li / M ratio is thus considered to be equal to unity for the structural refinements.

In order to determine accurately the structure of these materials, refinements by the Rietveld method of the XRD data were performed using the Fullprof program [63]. Firstly, a full pattern matching refinement allowed to determine the lattice parameters ( $a_{\text {hex. }}$ and $c_{\text {hex. }}$ ) and the profile parameters of the pseudo-Voigt function used to describe the shape of the diffraction lines. As shown in Table 2, the lattice parameters were found very similar for the three " $\mathrm{LiNi}_{0.425} \mathrm{Mn}_{0.425} \mathrm{CO}_{0.15} \mathrm{O}_{2}$ " materials: The ratio $c_{\text {hex. }} / a_{\text {hex. }}$ is equal to 4.96 , which indicates a good lamellar character for these materials.

Then, the structural refinements were carried out, considering the Li / $\mathrm{M}$ ratio equal to unity, in agreement with the iodometric titrations (oxid. state $\approx 3.00$ ) and a preferential presence of the lithium ions and the transition metal ions in the interslab space and in the slab, respectively. For instance, in the case of " $\mathrm{LiNi}_{0.425} \mathrm{Mn}_{0.425} \mathrm{CO}_{0.15} \mathrm{O}_{2}$ " synthesized by the classical coprecipitation method, we considered $\mathrm{Li} / \mathrm{M}=1$ with one $\mathrm{Li}$ in the $3 b(0,0,1 / 2)$ site, $0.425 \mathrm{Ni}, 0.425 \mathrm{Mn}$ and $0.15 \mathrm{Co}$ in the $3 a(0,0,0)$ site and one 0 in the $6 c\left(0,0, z_{\text {ox }}\right)$ site $\left(z_{\text {ox }}\right.$ being close to 0.25$)$. The occupancy ratios at the $3 a, 3 b$ and $6 c$ sites were fixed to their experimental values while the isotropic atomic displacement parameters $\left(B_{\text {iso }}\left(\AA^{2}\right)\right)$ were refined. A negative value was obtained for the $B_{\text {iso }}(\mathrm{Li})$ parameter $\left(B_{\text {iso }}(\mathrm{Li})=-2.14 \AA^{2}\right)$, showing thus an excess of electronic density due to the presence of transition metal ions in the interslab space, which was not taken into account by this first structural model. In a second hypothesis, we thus assumed the presence of extra $\mathrm{Ni}^{2+}$ ions in the lithium sites; indeed, the small difference in size between the $\mathrm{Ni}^{2+}$ and the $\mathrm{Li}^{+}$ions $\left(r\left(\mathrm{Ni}^{2+}\right)=0.69 \AA\right.$, $r\left(\mathrm{Li}^{+}\right)=0.72 \AA$ in octahedral environment) in contrast with the other cations $\left(r\left(\mathrm{Co}^{3+}\right)=0.54 \AA\right.$; $r\left(\mathrm{Mn}^{4+}\right)=0.53 \AA$ ) suggests that the excess of electronic density on the lithium site is due to the presence of extra $\mathrm{Ni}^{2+}$ ions. As the $\mathrm{Li} / \mathrm{M}$ ratio was equal to 1 , we assume a $\mathrm{Li}^{+} / \mathrm{Ni}^{2+}$ mixing between the slab and the interslab space. In "LiNi ${ }_{0.425} \mathrm{Mn}_{0.425} \mathrm{CO}_{0.15} \mathrm{O}_{2}$ ", the presence of a large amount of $\mathrm{Ni}^{2+}$ ions makes easier this mixing, in good agreement with the results obtained by one of us for the $\mathrm{Li}_{1-z} \mathrm{Ni}_{1+z} \mathrm{O}_{2}$ system for $z>30 \%$ [7]. We thus considered the formula $\left(\mathrm{Li}_{1-z} \mathrm{Ni}_{z}\right)_{3 b}\left(\mathrm{Li}_{z} \mathrm{Ni}_{0.425-z} \mathrm{Mn}_{0.425} \mathrm{Co}_{0.15}\right)_{3 a} \mathrm{O}_{2}$ : the occupancy ratio $(z)$ of the $\mathrm{Ni}^{2+}$ ions at the $3 b$ site was refined and constrained to be equal to that of the $\mathrm{Li}^{+}$ions at the $3 a$ site, with the total nickel occupancy ratio constrained to 0.425 . The main parameters deduced from the refinements of the XRD data and the cationic distributions determined for the three materials are summarized in Table 2 and Table 3 . The $\mathrm{Ni}^{2+}$ ions occupancy in the interslab space is about $7 \%$ for the three materials, 
which confirms that the partial cobalt substitution for nickel and manganese improves the lamellar character of the $\mathrm{LiNi}_{1 / 2} \mathrm{Mn}_{1 / 2} \mathrm{O}_{2} \geqslant$ type materials that were characterized, whatever the synthesis conditions, by a rather large amount of $\mathrm{Ni}^{2+}$ ions in the interslab space (between $8 \%$ and $13 \%$ ) [23], [24], [25], [26] and [39]. The slab thickness $\mathrm{S}\left(\mathrm{LiO}_{2}\right)$ and the interslab space thickness $\mathrm{I}\left(\mathrm{LiO}_{2}\right)$ are very similar for the three "LiNi ${ }_{0.425} \mathrm{Mn}_{0.425} \mathrm{CO}_{0.15} \mathrm{O}_{2}$ " materials.

Good agreements were obtained between the experimental and the calculated diffraction patterns in the three cases. For instance, Fig. 2 shows the comparison between the observed and calculated diffraction patterns of " $\mathrm{LiNi}_{0.425} \mathrm{Mn}_{0.425} \mathrm{CO}_{0.15} \mathrm{O}_{2}$ " prepared by the classical coprecipitation method. The reliability factors $\left(R_{\mathrm{B}}=3.07 \%\right.$ and $\left.R_{\mathrm{wp}}=9.74 \%\right)$ and the difference pattern $\left(I_{\mathrm{obs}}-I_{\text {calc }}\right)$ are rather good. However, very small discrepancies are observed in the difference curve; for instance, in the observed pattern, the (018) diffraction line is slightly more intense than the (110) one whereas these intensities are equal in the calculated pattern.

\subsection{Magnetic characterization}

As it was previously shown for $\mathrm{LiNiO}_{2}$-type materials, the presence of paramagnetic ions in the interslab space should greatly affect their magnetic properties. Indeed, it was shown for $\mathrm{Li}_{1-z} \mathrm{Ni}_{1+z} \mathrm{O}_{2}$ that strong antiferromagnetic $180^{\circ} \mathrm{Ni}-\mathrm{O}-\mathrm{Ni}$ interactions between the paramagnetic ions in the slab and those in the interslab space lead to the formation of ferrimagnetic domains, whose number and size increase with the occupancy $(z)$ of $\mathrm{Ni}^{2+}$ ions in the interslab space [64]. Fig. 3 shows the comparison of the hysteresis loops $M=f(H)$ ( $M$ for magnetization and $H$ for applied field) for the three "LiNi ${ }_{0.425} \mathrm{Mn}_{0.425} \mathrm{Co}_{0.15} \mathrm{O}_{2}$ " materials. These results are, as expected, similar to that of "LiNi $\mathrm{Li}_{1} \mathrm{Mn}_{1 / 2} \mathrm{O}_{2}$ " [41]: indeed, all of them are lamellar structures with the nickel and manganese ions at the divalent and the tetravalent states, respectively. The residual magnetization observed for the three materials when no field was applied indicates the presence at $5 \mathrm{~K}$ of some ferromagnetic interactions in "LiNi ${ }_{0.425} \mathrm{Mn}_{0.425} \mathrm{CO}_{0.15} \mathrm{O}_{2}$ " that could be attributed by analogy with previous studies [65] and [66] to the presence of some paramagnetic ions in the interslab space and thus to strong $180^{\circ} \mathrm{Ni}-\mathrm{O}-\mathrm{Ni}$ interactions between the slab and the interslab space. The narrower hysteresis loop observed for " $\mathrm{LiNi}_{0.425} \mathrm{Mn}_{0.425} \mathrm{Co}_{0.15} \mathrm{O}_{2}$ " prepared by the hydroxide route and the freeze-drying route might be explained by the slightly smaller amount of $\mathrm{Ni}^{2+}$ ions in the interslab space as determined by refinement of the X-ray data. As shown in Fig. 4, the thermal evolution of the $H$ / $M$ ratio, similar for all the "LiNi ${ }_{0.425} \mathrm{Mn}_{0.425} \mathrm{Co}_{0.15} \mathrm{O}_{2}$ " materials, is characteristic of a ferrimagnetic material: $\theta_{\mathrm{p}}$ (the intercept of the Curie-Weiss-type domain (above $150 \mathrm{~K}$ ) with the temperature axis) is negative. The experimental Curie constants and the theoretical ones, calculated from the cationic distributions determined by the refinement of the X-ray diffraction data, were found to be in rather good agreement for the three materials: they are summarized in Table 4. Magnetic measurements confirmed thus the presence of paramagnetic ions in the interslab space with the formation of ferrimagnetic domains. They are in good agreement with the overall chemical formula determined by the chemical analyses.

\subsection{Electrochemical tests}

The electrochemical behavior of " $\mathrm{LiNi}_{0.425} \mathrm{Mn}_{0.425} \mathrm{CO}_{0.15} \mathrm{O}_{2}$ " prepared by the different synthesis routes was investigated in galvanostatic mode at a constant $C / 20$ rate in the $2 \mathrm{~V}-4.5 \mathrm{~V}$ range. Fig. $5 \mathrm{a}-\mathrm{C}$ shows the variation of cell voltage versus lithium composition for " $\mathrm{LiNi} \mathrm{Ni}_{0.425} \mathrm{Mn}_{0.425} \mathrm{CO}_{0.15} \mathrm{O}_{2}$ " prepared by the three different synthesis routes. As these results given as examples were reproducible, the electrochemical performances were shown to be quite dependent on the synthesis conditions for "LiNi $\mathrm{L}_{0.425} \mathrm{Mn}_{0.425} \mathrm{Co}_{0.15} \mathrm{O}_{2}$ ".

The reversible capacity obtained for the first cycle was very good ( $>180 \mathrm{mAh} / \mathrm{g}$ ) for the materials synthesized by the classical coprecipitation and hydroxide routes, with a larger irreversible capacity ( $25 \mathrm{vs.} 20 \mathrm{mAh} / \mathrm{g})$ and a stronger polarization ( $0.5 \mathrm{vs} .0 .25 \mathrm{~V}$ ) for the latter one. Note that upon further cycling, a rapid loss of reversible capacity was observed for the "LiNi ${ }_{0.425} \mathrm{Mn}_{0.425} \mathrm{CO}_{0.15} \mathrm{O}_{2}$ " synthesized by the hydroxide route whereas it remained quite stable for that synthesized by the classical coprecipitation route. Concerning " $\mathrm{LiNi}_{0.425} \mathrm{Mn}_{0.425} \mathrm{Co}_{0.15} \mathrm{O}_{2}$ " synthesized by the freeze-drying coprecipitation method, a rather small reversible capacity is already observed at the first cycle (140 $\mathrm{mAh} / \mathrm{g})$, with a strong polarization $(0.5 \mathrm{~V})$ and a quite large irreversible capacity $(25 \mathrm{mAh} / \mathrm{g})$.

Despite a decreasing amount of transition metal ions in the interslab space with Co substitution in comparison with that observed for $\mathrm{LiNi}_{1 / 2} \mathrm{Mn}_{1 / 2} \mathrm{O}_{2}$, it remains significant ( $>7 \%$ ) and was expected to induce a strong worsening of the electrochemical performances by comparison with the $\mathrm{Li}_{1-z} \mathrm{Ni}_{1+z} \mathrm{O}_{2}(z=7 \%)$ lithium nickelate system [7]. But on the contrary to $\mathrm{Li}_{1-z} \mathrm{Ni}_{1+z} \mathrm{O}_{2}$, in the 
$\mathrm{Li}(\mathrm{Ni}, \mathrm{Mn}, \mathrm{Co}) \mathrm{O}_{2}$ materials lithium ions are present not only in the interslab space but also in the slab, therefore 3D diffusion pathways for lithium ions may be responsible for the attractive electrochemical performances of this system despite the presence of a significant amount of transition metal ions in the interslab space.

The derivative curves $-\mathrm{d} x / \mathrm{d} V \mid=f(V)$ given in Fig. 5 do not exhibit any sharp peak, which suggests that no first order phase transition occurs upon charge and discharge for "LiNi $\mathrm{L}_{0.425} \mathrm{Mn}_{0.425} \mathrm{CO}_{0.15} \mathrm{O}_{2}$ ". Indeed, because a large amount of nickel and lithium ions are present in the interslab space and slab, respectively, the Li/vacancy and charge orderings that were at the origin of the phase transitions in $\mathrm{LiNiO}_{2}$ cannot be established [67] and [68].

As such differences in electrochemical behavior could not only be attributed to the structure of the materials that were shown to be very similar according to the X-ray diffraction data and magnetic measurements, the texture was studied using scanning electron microscopy, particle size and specific surface area measurements.

\subsection{Textural characterizations}

Particle morphology and size were investigated by high resolution scanning electron microscopy. Fig. 6 gives a comparison of the SEM micrographs obtained for the three " $\mathrm{LiNi}_{0.425} \mathrm{Mn}_{0.425} \mathrm{Co}_{0.15} \mathrm{O}_{2}$ " materials. That prepared by the classical coprecipitation method was made of small aggregates of quite well shaped particles characterized by a diameter around 0.5-0.8 $\mu \mathrm{m}$. In contrast with that material, the materials synthesized by the hydroxide and freeze-dried coprecipitation routes exhibited very large aggregates ( $>20 \mu \mathrm{m}$ ) made of primary particles in the $0.8-1 \mu \mathrm{m}$ range.

Fig. 7 compares the particle size distributions in volume and in number of particles for " $\mathrm{LiNi}_{0.425} \mathrm{Mn}_{0.425} \mathrm{CO}_{0.15} \mathrm{O}_{2}$ " prepared by the three methods. In volume, all the materials are characterized by a large volume distribution resulting from two populations, one centered around 2 $\mu \mathrm{m}$ and another around 20-40 $\mu \mathrm{m}$. Note that the biggest aggregates were observed for the material synthesized by the freeze-drying coprecipitation method. Concerning the particle size distribution in number, a population centered around $0.5 \mu \mathrm{m}$ is observed for " $\mathrm{LiNi} 0.425 \mathrm{Mn}_{0.425} \mathrm{Co}_{0.15} \mathrm{O}_{2}$ " prepared by the classical coprecipitation route, and centered around $0.8 \mu \mathrm{m}$ for those prepared by the two other synthesis methods. Note that no population could be observed in the range 20-40 $\mu \mathrm{m}$, which means that the number of these aggregates was negligible versus the number of particles with diameter below $1 \mu \mathrm{m}$. However these very large aggregates are those representing a large active material mass; therefore it is important to consider them in order to explain the electrochemical results. For instance, the big aggregates observed for the material synthesized by the freeze-drying coprecipitation method were quite dense, which may hinder their impregnation by electrolyte and thus cause the initial polarization of the lithium cell.

Table 5 reports the specific surface area measured by the B.E.T. method for the three materials mentioned above. The largest specific surface area was found for the material prepared by the classical coprecipitation method and the smallest for that prepared by the freeze-drying coprecipitation method, which is also in agreement with the scanning electron micrographs and particle size distributions in number.

From a textural point of view, small particles for " $\mathrm{LiNi}_{0.425} \mathrm{Mn}_{0.425} \mathrm{CO}_{0.15} \mathrm{O}_{2}$ " allow a fast lithium diffusion and lead thus to a lower polarization, hence a higher reversible capacity of the lithium cell. In contrast, big particles lead to a strong initial polarization and hence to a poor reversible capacity. The material synthesized by the classical coprecipitation method was characterized by the smallest primary particles and the highest porosity, i.e., by the easiest access for electrolyte and conductive additives.

\section{Conclusion}

In this work, well crystallized "LiNi ${ }_{0.425} \mathrm{Mn}_{0.425} \mathrm{Co}_{0.15} \mathrm{O}_{2}$ " materials were prepared by three different methods i.e., the classical coprecipitation, the freeze-drying coprecipitation and the hydroxide routes. Rietveld refinements of the XRD data and magnetic measurements showed similar overall chemical formula and cationic distributions for these $\mathrm{Li}(\mathrm{Ni}, \mathrm{Mn}, \mathrm{Co}) \mathrm{O}_{2}$ materials. However, cycling tests have revealed great differences in their electrochemical behaviors. The best electrochemical performances were observed for the material prepared by the classical coprecipitation method that was also characterized by the largest specific surface area $\left(2.1 \mathrm{~m}^{2} / \mathrm{g}\right)$ and the smallest average particle size $(0.5 \mu \mathrm{m})$. Therefore, it is believed that the texture of the " $\mathrm{LiNi}_{0.425} \mathrm{Mn}_{0.425} \mathrm{Co}_{0.15} \mathrm{O}_{2}$ " 
positive electrode material influences largely the electrode preparation and thus the performance in lithium batteries.

\section{Acknowledgements}

The authors thank C. Denage (ICMCB, Pessac, France) and K. Sakamoto (ICMCB, Pessac, France) for the technical assistance, A. Lecerf (INSA, Rennes, France) for fruitful discussions, SAFT and Region Aquitaine for financial support.

\section{References}

[1] M.G.S.R. Thomas, P.G. Bruce and J.B. Goodenough, Solid State Ionics 13 (1985), p. 17.

[2] J.R. Dahn, U. Von Sacken, M.W. Juzkow and H. Al-Janaby, J. Electrochem. Soc. 2207 (1991), p. 138.

[3] M. Broussely, F. Perton, J. Labat, R.J. Staniewicz and A. Romero, J. Power Sources 209 (1993), pp. 43-44.

[4] T. Ohzuku and A. Ueda, Solid State Ionics 201 (1994), p. 69.

[5] C. Delmas, M. Ménétrier, L. Croguennec, I. Saadoune, A. Rougier, C. Pouillerie, G. Prado, M. Grüne and L. Fournès, Electrochim. Acta 243 (1999), p. 45.

[6] R. Kanno, H. Kubo, Y. Kawamoto, T. Kamiyama, F. Izumi, Y. Takeda and M. Takano, J. Solid State Chem. 216 (1994), p. 110.

[7] A. Rougier, P. Gravereau and C. Delmas, J. Electrochem. Soc. 1168 (1996), p. 143.

[8] J.P. Pérès, C. Delmas, A. Rougier, M. Broussely, F. Perton, P. Biensan and P. Willmann, J. Phys. Chem. Solids 1057 (1996), p. 57.

[9] M. Broussely, F. Perton, P. Biensan, J.M. Bodet, J. Labat, A. Lecerf, C. Delmas, A. Rougier and J.P. Pérès, J. Power Sources 109 (1995), p. 54.

[10] J.R. Dahn, E.W. Fuller, M. Obrovac and U. Von Sacken, Solid State Ionics 265 (1994), p. 69.

[11] T. Ohzuku, A. Ueda and M. Kouguchi, J. Electrochem. Soc. 4033 (1995), p. 142.

[12] H. Arai, S. Okada, Y. Sakurai and J. Yamaki, Solid State Ionics 295 (1998), p. 109.

[13] C. Delmas and I. Saadoune, Solid State Ionics 370 (1992), pp. 53-56.

[14] C. Delmas, I. Saadoune and A. Rougier, J. Power Sources 595 (1993), pp. 43-44.

[15] E. Zhecheva and R. Stoyanova, Solid State Ionics 143 (1993), p. 66.

[16] A. Ueda and T. Ohzuku, J. Electrochem. Soc. 2010 (1994), p. 141.

[17] A. Rougier, I. Saadoune, P. Gravereau, P. Willmann and C. Delmas, Solid State Ionics 83 (1996), p. 90.

[18] M. Guilmard, A. Rougier, M. Grüne, L. Croguennec and C. Delmas, J. Power Sources 305 (2003), p. 115.

[19] Q. Zhong and U. Von Sacken, J. Power Sources 221 (1995), p. 54.

[20] G.X. Wang, S. Zhong, D.H. Bradhurst, S.X. Dou and H.K. Liu, Solid State Ionics 271 (1999), p. 116. 
[21] S.H. Park, K.S. Park, Y.K. Sun, K.S. Nahm, Y.S. Lee and M. Yoshio, Electrochim. Acta 1215 (2001), p. 46.

[22] C. Pouillerie, L. Croguennec, P. Biensan, P. Willmann and C. Delmas, J. Electrochem. Soc. 2061 (2000), p. 147.

[23] H. Arai, S. Okada, Y. Sakurai and J. Yamaki, J. Electrochem. Soc. 3117 (1997), p. 144.

[24] T. Ohzuku and Y. Makimura, Chem. Lett. 642 (2001).

[25] S.H. Chang, S. Kang, S. Song, J. Yoon and J. Choy, Solid State Ionics 171 (1996), pp. 86-88.

[26] S. Venkatraman and A. Manthiram, Chem. Mater. 5003 (2003), p. 15.

[27] L. Croguennec, E. Suard, P. Willmann and C. Delmas, Chem. Mater. 2149 (2002), p. 14.

[28] G. Prado, A. Rougier, L. Fournès and C. Delmas, J. Electrochem. Soc. 2880 (2000), p. 147.

[29] Y. Nishida, K. Nakane and T. Satoh, J. Power Sources 561 (1997), p. 68.

[30] Y. Sato, T. Koyano, M. Mukai and K. Kobayakawa, Denki Kagaku 1215 (1998), p. 66.

[31] M. Broussely, P. Blanchard, P. Biensan, J.P. Planchat, K. Nechev and R.J. Staniewicz, J. Power Sources 859 (2003), p. 119.

[32] T. Ohzuku and Y. Makimura, Chem. Lett. 744 (2001).

[33] Y. Makimura and T. Ohzuku, J. Power Sources 156 (2003), p. 119.

[34] Y. Koyama, Y. Makimura, I. Tanaka, H. Adachi and T. Ohzuku, J. Electrochem. Soc. A1499 (2004) (9), p. 151.

[35] T. Ohzuku, M. Ariyoshi, Y. Makimura, N. Yabuuchi and K. Sawai, Electrochemistry 2 (2005), p. 73.

[36] P.G. Bruce, A.R. Armstrong and R.L. Gitzendanner, J. Mater. Chem. 193 (1999), p. 9.

[37] L. Croguennec, P. Deniard and R. Brec, J. Electrochem. Soc. 3323 (1997), p. 144.

[38] F. Capitaine, Thesis, Bordeaux I (1997).

[39] K. Sakamoto, N. Tran, L. Croguennec, C. Delmas, submitted for publication to Journal of Power Sources.

[40] S. Gopukumar, K.Y. Chung and K.B. Kim, Electrochim. Acta 803 (2004), p. 49.

[41] H. Kobayashi, H. Sakaebe, H. Kageyama, K. Tatsumi, Y. Arachi and T. Kamiyama, J. Mater. Chem. 590 (2003), p. 13.

[42] I. Saadoune and C. Delmas, J. Mater. Chem. 193 (1996), p. 6.

[43] S. Jouanneau, K.W. Eberman, L.J. Krause and J.R. Dahn, J. Electrochem. Soc. A1637 (2003), p. 150.

[44] D.C. Li, T. Muta, L.Q. Zhang, M. Yoshio and H. Noguchi, J. Power Sources 150 (2004), p. 132.

[45] Y. Koyama, N. Yabuuchi, I. Tanaka, H. Adachi and T. Ohzuku, J. Electrochem. Soc. A1545 (2004), p. 151.

[46] K.M. Shaju, G.V.S. Rao and B.V.R. Chowdari, J. Electrochem. Soc. A1324 (2004), p. 151. 
[47] J.K. Ngala, N.A. Chernova, M.M. Ma, M. Mamak, P.Y. Zavalij and M.S. Whittingham, J. Mater. Chem. 214 (2004), p. 14.

[48] Z.X. Wang, Y.C. Sun, L.Q. Chen and X.J. Huang, J. Electrochem. Soc. A914 (2004), p. 151.

[49] B.J. Hwang, Y.W. Tsai, D. Carlier and G. Ceder, Chem. Mater. 3676 (2003), p. 15.

[50] B.J. Hwang, Y.W. Tsai, C.H. Chen and R. Santhanam, J. Mater. Chem. 1962 (2003), p. 13.

[51] W.S. Yoon, C.P. Grey, M. Balasubramanian, X.Q. Yang, D.A. Fischer and J. McBreen, Electrochem. Solid-State Lett. A53 (2004), p. 7.

[52] Y.K. Sun, S.H. Kang and K. Amine, Mater. Res. Bull. 819 (2004), p. 39.

[53] Y.C. Sun, C. Ouyang, Z.X. Wang, X.J. Huang and L.Q. Chen, J. Electrochem. Soc. A504 (2004), p. 151.

[54] S. Jouanneau, D.D. MacNeil, Z. Lu, S.D. Beattie, G. Murphy and J.R. Dahn, J. Electrochem. Soc. A1299 (2003), p. 150.

[55] D.D. MacNeil, Z. Lu and J.R. Dahn, J. Electrochem. Soc. A1332 (2002), p. 149.

[56] H. Yoshizawa and T. Ohzuku, Electrochemistry 1177 (2003), p. 71.

[57] N. Yabuuchi and T. Ohzuku, J. Power Sources 171 (2003), p. 119 (Special Iss. SI).

[58] C.C. Chang, J.Y. Kim and P.N. Kumta, J. Electrochem. Soc. A1114 (2002), p. 149.

[59] D. Caurant, N. Baffier, B. Garcia and J.P. Pereira-Ramos, Solid State Ionics 45 (1996), p. 91.

[60] N. Tran, L. Croguennec, C. Labrugère, C. Jordy, P. Biensan and C. Delmas, J. Electrochem. Soc., submitted for publication.

[61] J. Morales, C. Pérez-Vicente and J.L. Tirado, Mater. Res. Bull. 623 (1990), p. 25.

[62] J.R. Dahn, U. Von Sacken and C.A. Michal, Solid State Ionics 87 (1990), p. 44.

[63] J. Rodriguez-Carjajal, Laboratoire Léon Brillouin, http://www-llb.cea.fr/fullweb/powder.html..

[64] A. Rougier, C. Delmas and G. Chouteau, J. Phys. Chem. Solids 1101 (1996), p. 57.

[65] A.L. Barra, G. Chouteau, A. Stepanov, A. Rougier and C. Delmas, Eur. Phys. J., B 551 (1999), p. 7.

[66] M. Guilmard, C. Pouillerie, L. Croguennec and C. Delmas, Solid State Ionics 39 (2003), p. 160.

[67] M. de Dompablo, A. Van der Ven and G. Ceder, Phys. Rev., B NI L_ 192 (2002), p. 6606.

[68] J.P. Pérès, F. Weill and C. Delmas, Solid State Ionics 19 (1999), p. 116.

[69] J.F. Berar and Lelann, J. Appl. Crystallogr. 1 (1991), p. 24. 

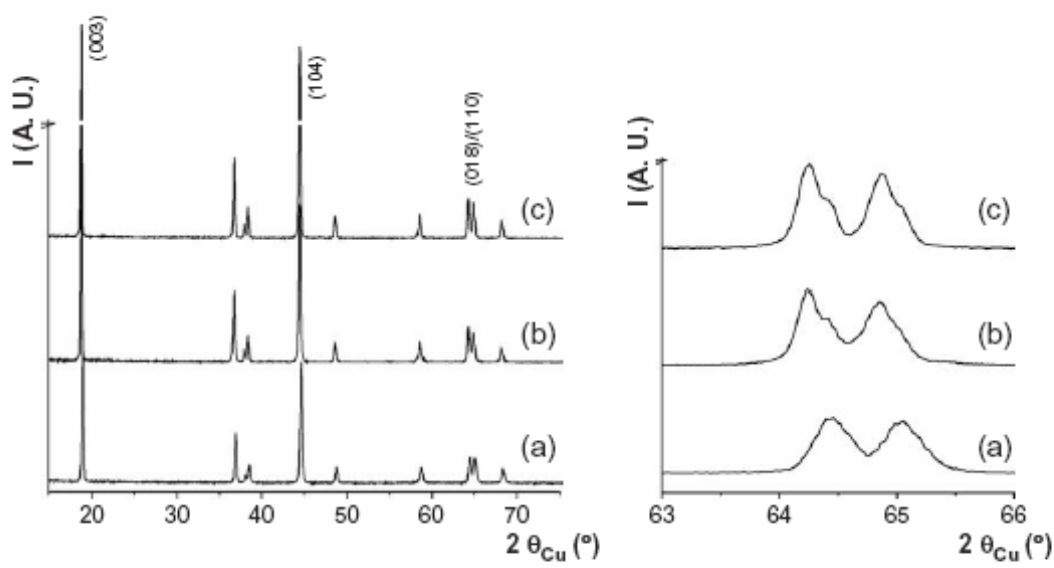

Fig. 1. X-ray diffraction patterns of " $\mathrm{LiNi}_{0.425} \mathrm{Mn}_{0.425} \mathrm{Co}_{0.15} \mathrm{O}_{2}{ }^{\prime}$ phases prepared (a) by the classical coprecipitation method, (b) by the freeze-drying coprecipitation method and (c) by the hydroxide route. Detailed diffraction data in the $63-66^{\circ}(2 \theta)$ range were added for each pattern.

Table 1

Average oxidation state (oxid. state) obtained by iodometric titration for the transition metal ions in " $\mathrm{LiNi}_{0.425} \mathrm{Mn}_{0.425} \mathrm{Co}_{0.15} \mathrm{O}_{2}$ " prepared by the three synthesis routes

\begin{tabular}{ll}
\hline${ }^{\circ} \mathrm{LiNi}_{0.425} \mathrm{Mn}_{0.425} \mathrm{Co}_{0.15} \mathrm{O}_{2}{ }^{\circ}$ & oxid. state \\
\hline Classical route & 3.00 \\
Freeze-drying route & 2.98 \\
Hydroxide route & 3.02 \\
\hline
\end{tabular}

Table 2

Structural parameters determined for " $\mathrm{LiNi}_{0.425} \mathrm{Mn}_{0.425} \mathrm{Co}_{0.15} \mathrm{O}_{2}{ }^{\prime}$ prepared by the three synthesis routes, by Rietveld refinement of their X-ray diffraction data

\begin{tabular}{llllll}
\hline & $a_{\text {hex. }}(\AA)$ & $c_{\text {hex. }}(\AA)$ & $\begin{array}{l}c_{\text {hex. }} / \\
a_{\text {hex. }}\end{array}$ & $\begin{array}{l}\mathrm{S}\left(\mathrm{MO}_{2}\right) \\
(\AA)\left(^{*}\right)\end{array}$ & $\begin{array}{l}\mathrm{I}\left(\mathrm{LiO}_{2}\right) \\
(\AA)(* *)\end{array}$ \\
\hline " $\mathrm{LiNi}_{0.425} \mathrm{Mn}_{0.425} \mathrm{Co}_{0.15} \mathrm{O}_{2} "$ & & & & \\
Classical route & $2.8797(1)$ & $14.287(1)$ & 4.96 & $2.17(1)$ & $2.60(1)$ \\
Freeze-drying route & $2.8801(1)$ & $14.290(1)$ & 4.96 & $2.16(1)$ & $2.60(1)$ \\
Hydroxide route & $2.8815(1)$ & $14.289(1)$ & 4.96 & $2.16(1)$ & $2.60(1)$ \\
\hline
\end{tabular}

The standard deviation was multiplied by the Scor parameter to correct for local correlations [69].

$\left.{ }^{*}\right)$ Slab thickness: $\mathrm{S}\left(\mathrm{MO}_{2}\right)=2\left(1 / 3-z_{\text {ox }}\right) c_{\text {hex }}$

(**) Interslab space thickness: $\mathrm{I}\left(\mathrm{LiO}_{2}\right)=c_{\text {hex. }} / 3-\mathrm{S}\left(\mathrm{MO}_{2}\right)$. 
Table 3

Cationic distributions determined for " $\mathrm{LiNi}_{0.425} \mathrm{Mn}_{0.425} \mathrm{Co}_{0.15} \mathrm{O}_{2}$ " prepared by the three synthesis routes, by Rietveld refinement of their X-ray diffraction data

\begin{tabular}{|c|c|c|c|c|c|c|}
\hline \multirow[t]{2}{*}{$" \mathrm{LiNi}_{0.425} \mathrm{Mn}_{0.425} \mathrm{Co}_{0.15} \mathrm{O}_{2}{ }^{\prime}$} & \multicolumn{2}{|c|}{ Interslab } & \multicolumn{4}{|l|}{$\underline{\text { Slab }}$} \\
\hline & $\mathrm{Li}^{+}$ & $\mathrm{Ni}^{2+}$ & $\mathrm{Li}^{+}$ & $\mathrm{Ni}^{2+}$ & $\mathrm{Mn}^{4+}$ & $\mathrm{Co}^{3+}$ \\
\hline & 0.922 & 0.078 & 0.078 & 0.347 & 0.425 & 0.150 \\
\hline & 0.931 & 0.069 & 0.069 & 0.356 & 0.425 & 0.150 \\
\hline Hydroxide route & 0.927 & 0.073 & 0.073 & 0.352 & 0.425 & 0.150 \\
\hline
\end{tabular}

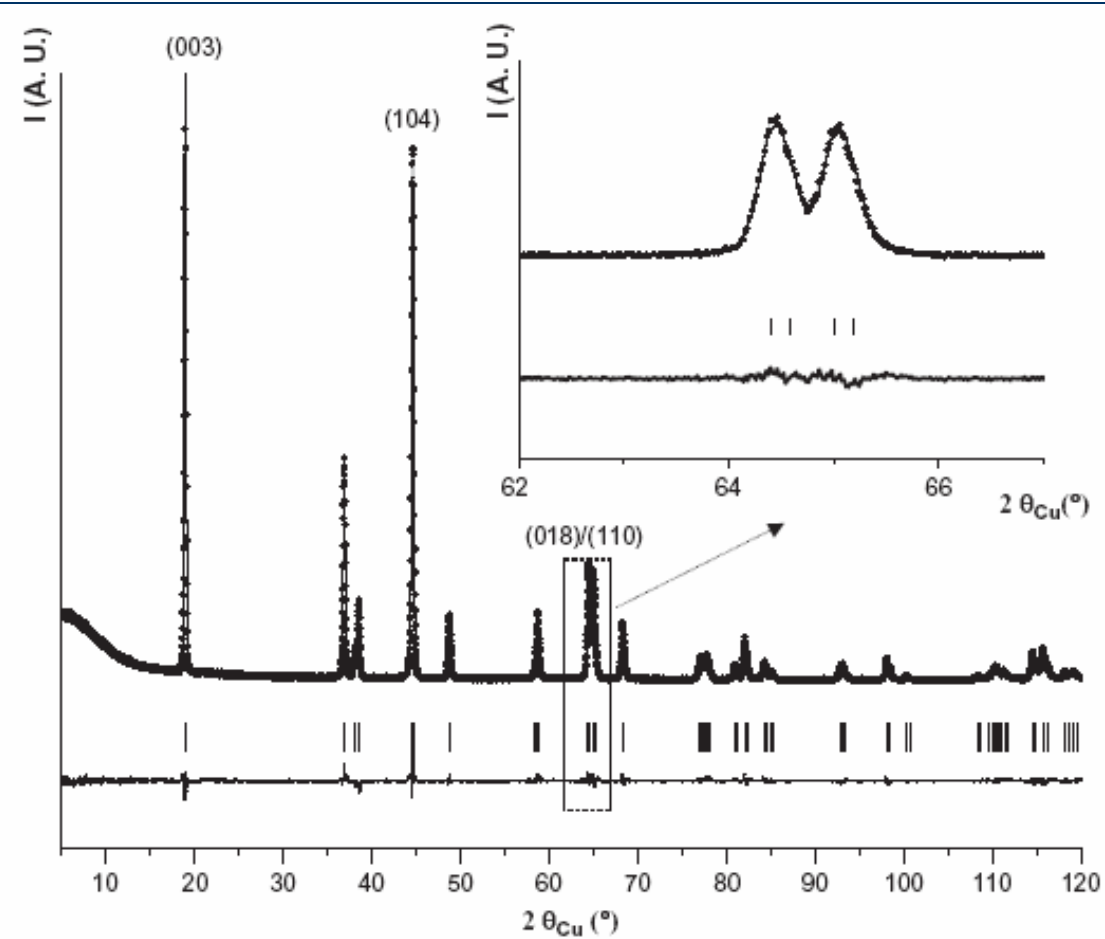

Fig. 2. Comparison of the experimental (-) and calculated (-) X-ray diffraction patterns of " $\mathrm{LiNi}_{0.425} \mathrm{Mn}_{0.425} \mathrm{Co}_{0.15} \mathrm{O}_{2}{ }$ " synthesized by the classical coprecipitation method. 


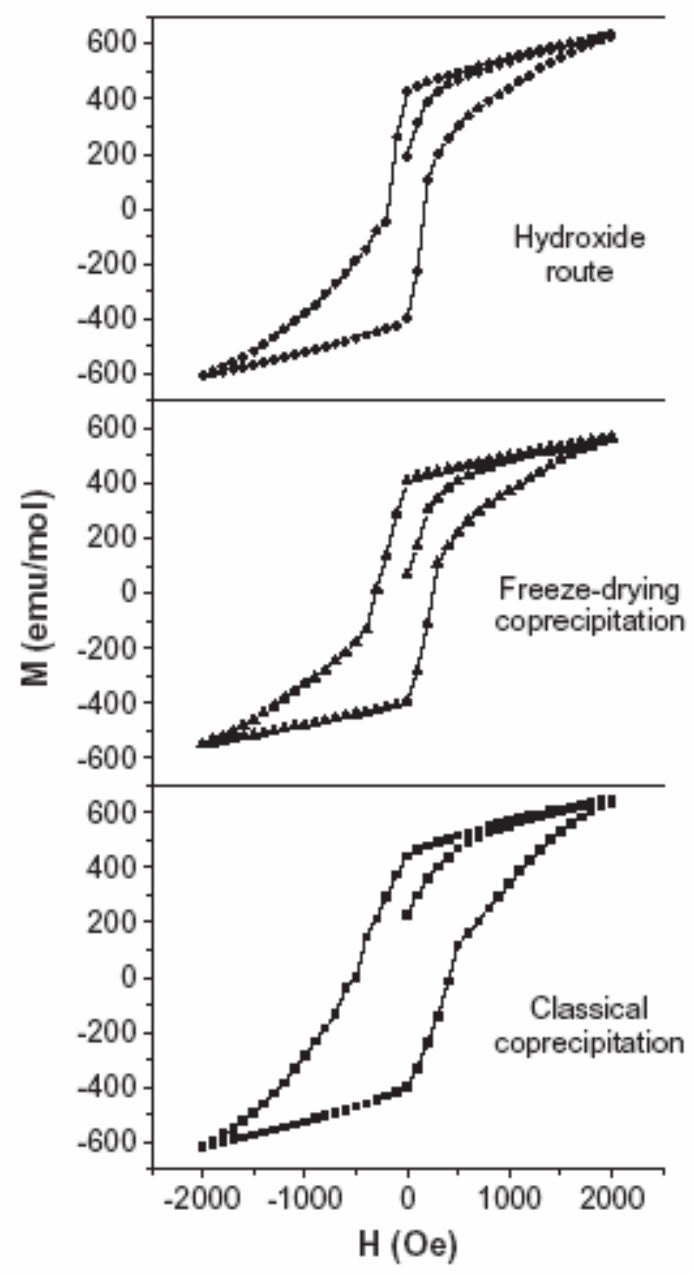

Fig. 3. Comparison of the hysteresis loops recorded at $5 \mathrm{~K}$ vs. magnetic field for the " $\mathrm{LiNi}_{0.425} \mathrm{Mn}_{0.425} \mathrm{Co}_{0.15} \mathrm{O}_{2}$ " phases prepared by different synthesis routes.

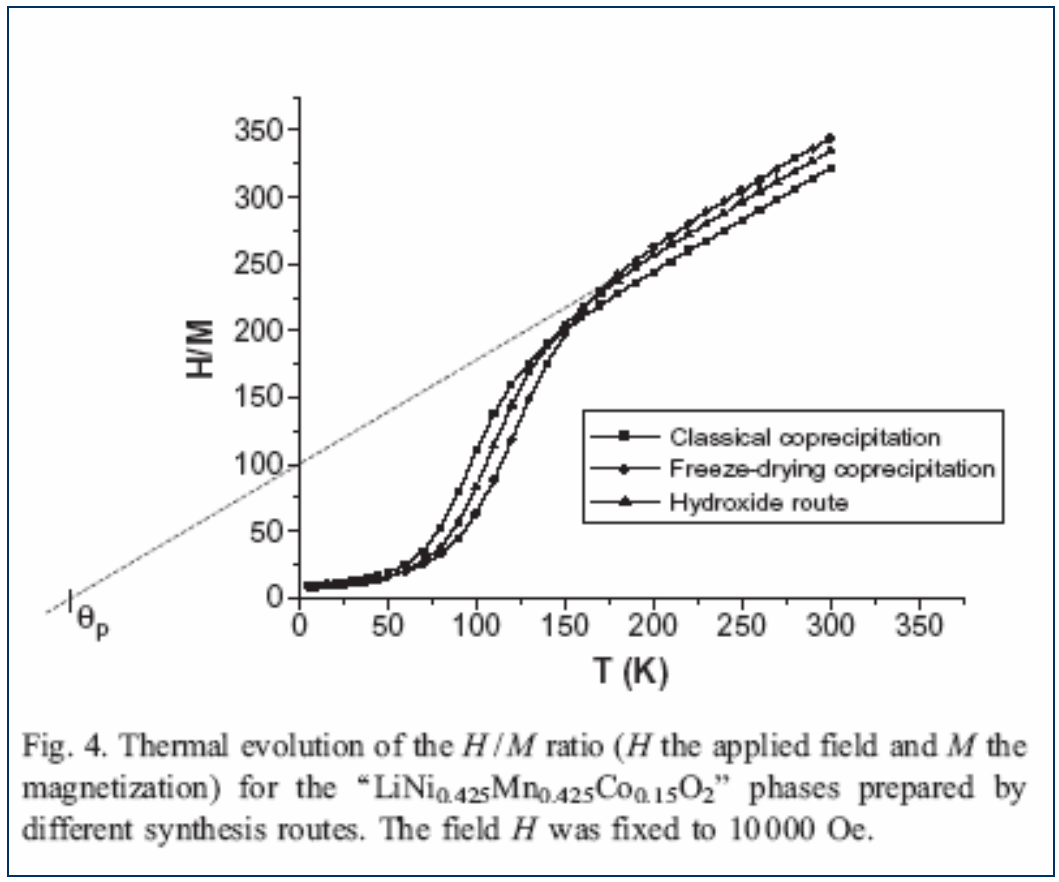


Table 4

Comparison between the experimental and the theoretical Curie-Weiss constants of " $\mathrm{LiNi}_{0.425} \mathrm{Mn}_{0.425} \mathrm{Co}_{0.15} \mathrm{O}_{2}$ " prepared by different synthesis routes

\begin{tabular}{lll}
\hline " $\mathrm{LiNi}_{0.425} \mathrm{Mn}_{0.425} \mathrm{Co}_{0.15} \mathrm{O}_{2} "$ & $C_{\exp .}$ & $C_{\text {th. }}$ \\
\hline Classical route & 1.25 & 1.22 \\
Freeze-drying route & 1.23 & 1.22 \\
Hydroxide route & 1.26 & 1.22 \\
\hline
\end{tabular}

The theoretical Curie-Weiss constants were calculated from the cationic distributions determined by Rietveld refinement of their X-ray diffraction data.
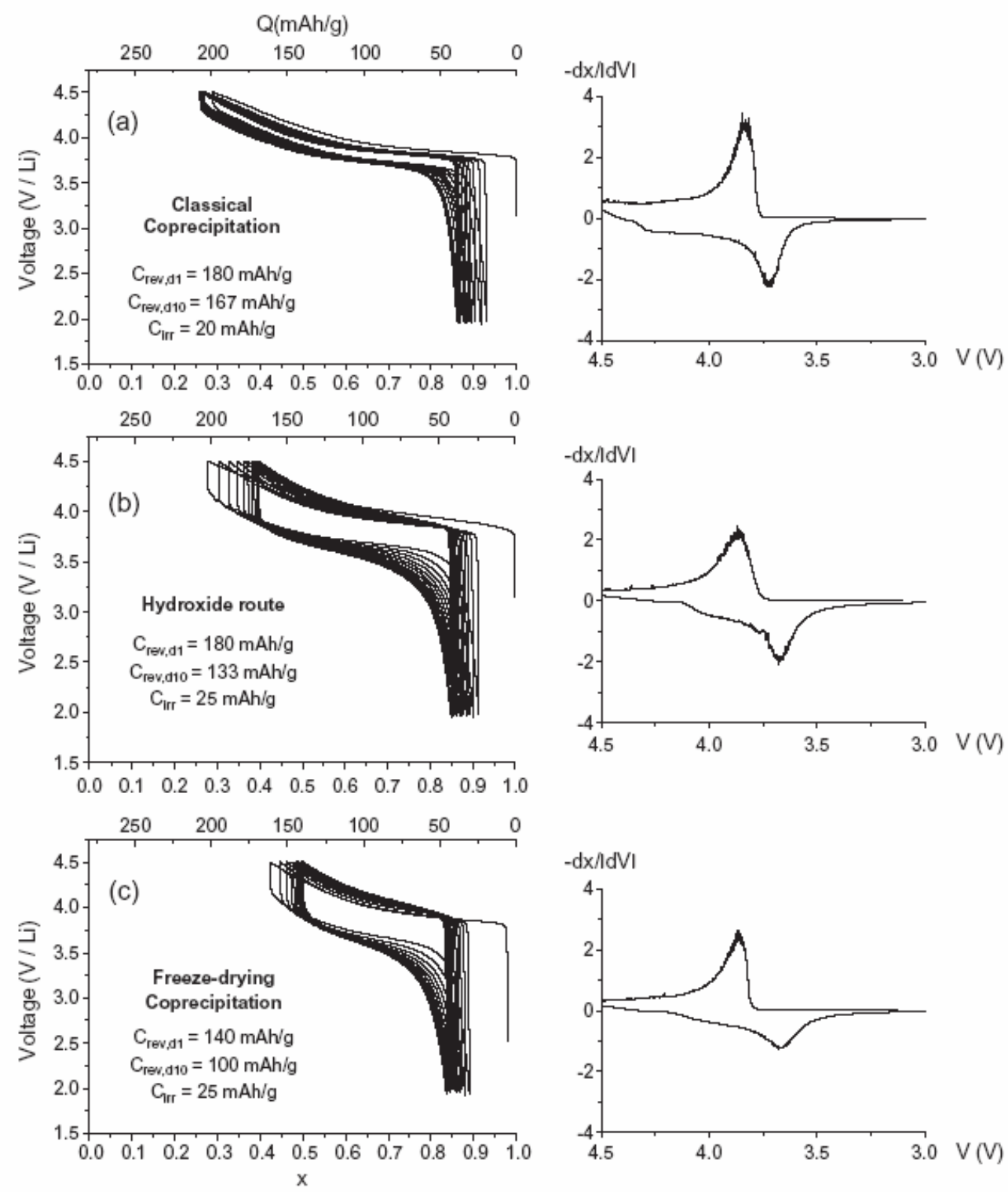

Fig. 5. (a-c): Variation of the voltage versus lithium amount at the $C / 20$ rate for the first 10 galvanostatic charge/discharge cycles of $\mathrm{Li} / /$ " $\mathrm{Li}_{\mathrm{x}} \mathrm{Ni}_{0.425} \mathrm{Mn}_{0.425} \mathrm{Co}_{0.15} \mathrm{O}_{2}$ " cells, where " $\mathrm{LiNi}_{0.425} \mathrm{Mn}_{0.425} \mathrm{CO}_{0.15} \mathrm{O}_{2}$ " was prepared by different synthesis routes. The first and the tenth discharge capacities are specified for each cell. The $-\mathrm{d} x /|\mathrm{d} V|=f(V)$ incremental capacity curves are also given for comparison. 


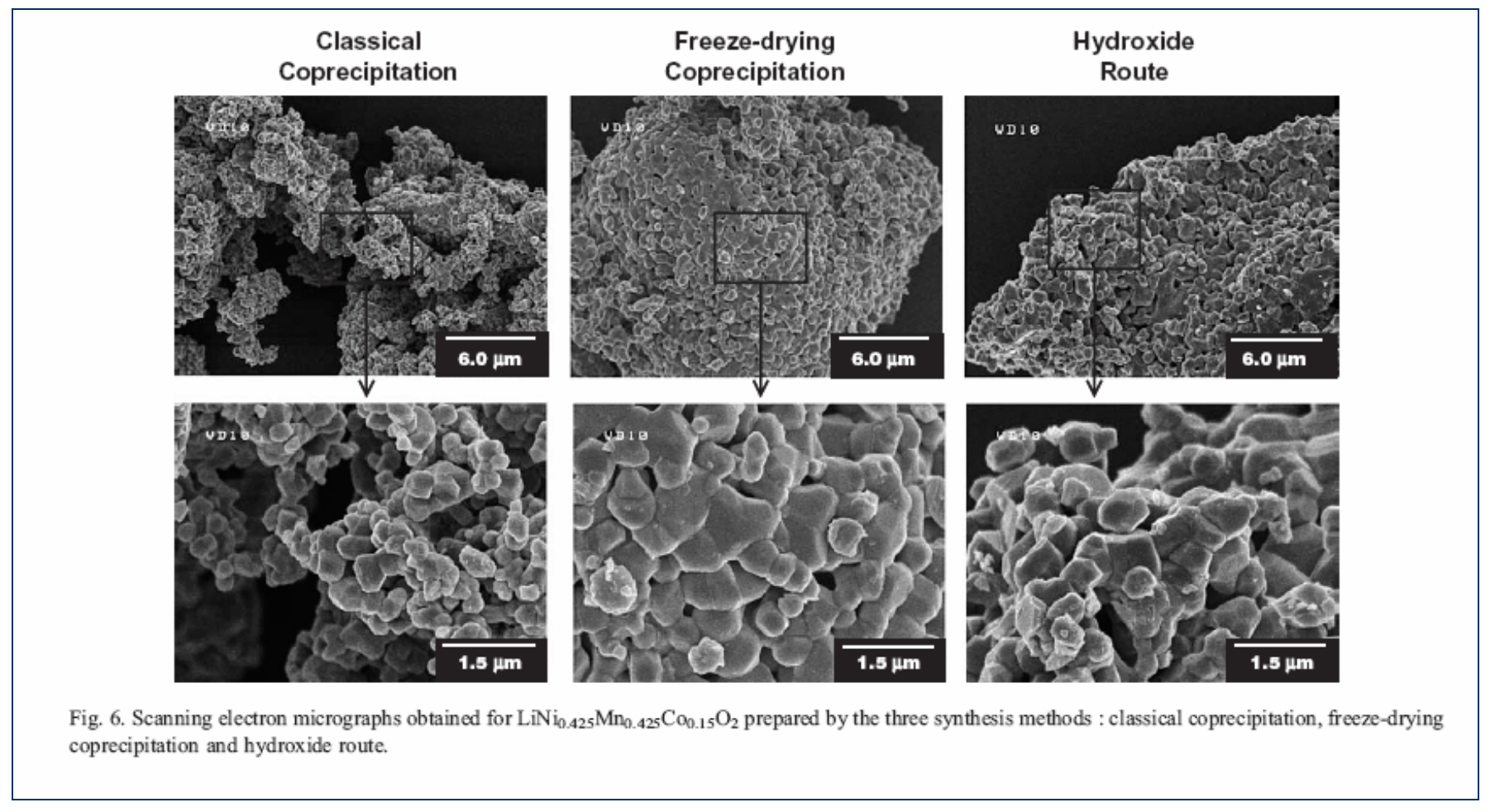



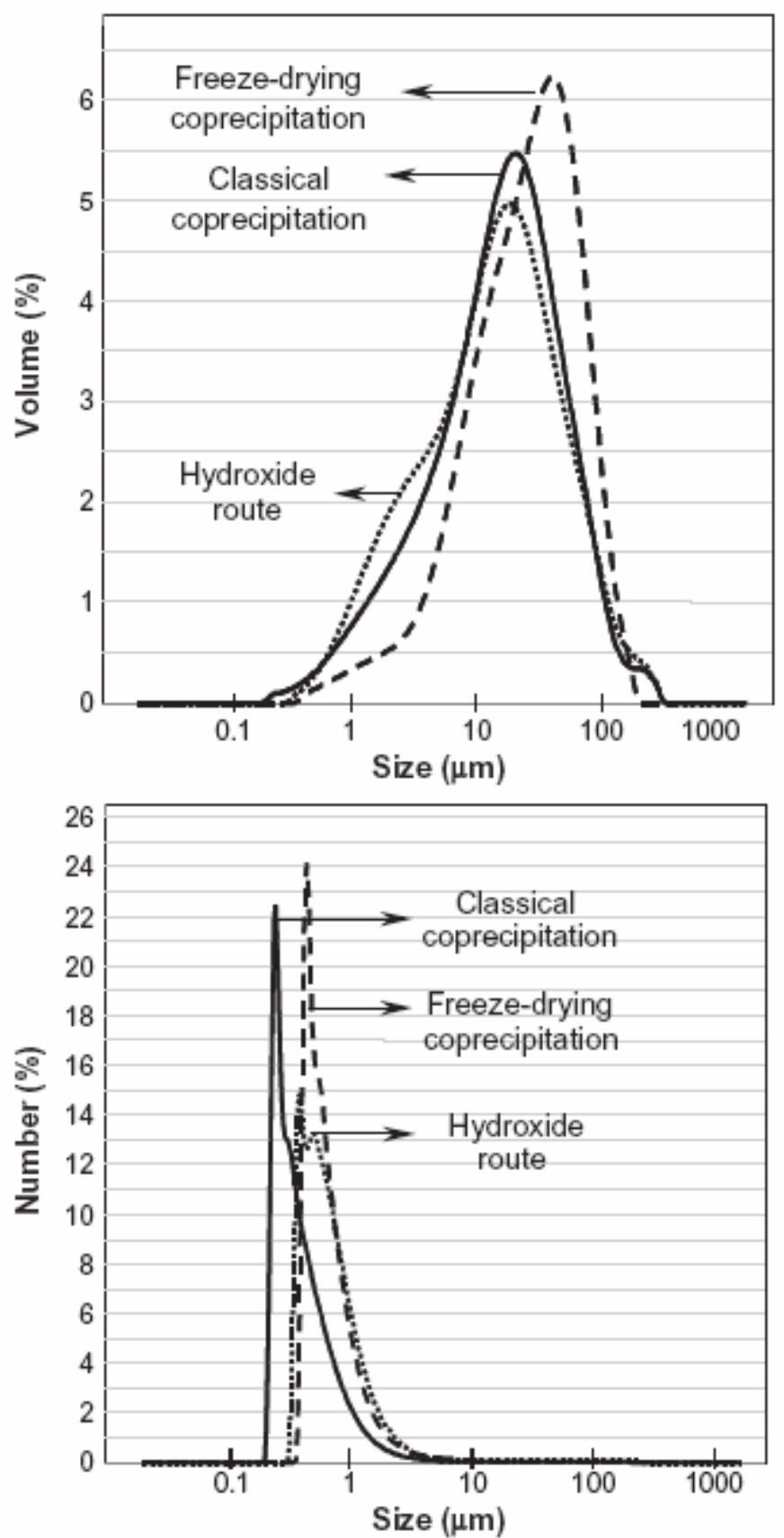

Fig. 7. Particle size distributions in volume (a) and in number (b) of " $\mathrm{LiNi}_{0.425} \mathrm{Mn}_{0.425} \mathrm{Co}_{0.15} \mathrm{O}_{2}$ " prepared by the three synthesis routes: classical coprecipitation, freeze-drying coprecipitation and hydroxide route.

Table 5

Comparison between the specific surface areas measured by the B.E.T. method for " $\mathrm{LiNi}_{0.425} \mathrm{Mn}_{0.425} \mathrm{Co}_{0.15} \mathrm{O}_{2}$ " prepared by different synthesis routes

\begin{tabular}{ll}
\hline${ }^{"} \mathrm{LiNi}_{0.425} \mathrm{Mn}_{0.425} \mathrm{Co}_{0.15} \mathrm{O}_{2}{ }^{"}$ & $S_{\text {B.ET. }}\left(\mathrm{m}^{2} / \mathrm{g}\right)$ \\
\hline Classical route & 2.10 \\
Freeze-drying route & 0.98 \\
Hydroxide route & 1.32 \\
\hline
\end{tabular}

i.e., by the easiest access for electrolyte and conductive additives. 